\title{
Piranti Bahasa dan Mistisime Jawa dalam Kumpulan Puisi Hujan Bulan Juni Karya Sapardi Djoko Damono
}

\author{
Tjahjono Widijanto dan Sumarlam
}

Universitas Sebelas Maret, Surakarta

\begin{abstract}
Abstrak
Kajian ini adalah ihtiar menganalisis bahasa sekaligus menafsirkan dan menjelajahi konteks sosial budaya puisi-puisi Sapardi Djoko Damono (SDD) yang terhimpun dalam kumpulan puisi Hujan Bulan Juni, diterbitkan Gramedia Pustaka Juni 2013. Pijakan awal kajian ini adalah stilistika dengan fokus menggali aspek-aspek kebahasaan seperti ragam bunyi, kata, simbol, imaji dan majas. Dalam kajian ini nampak pusi-puisi SDD didominasi suasana ketertekanan, keheningan, dan kefanaan dengan bersandar pada kekuatan cacphony, gaya paradaksol dengan mempertentangkan kata yang mempunyai dua sifat berbeda, menghadirkan pada diri pembacanya imaji yang membangun ruang-ruang misteri. Pemilihan kata dengan cermat dipilih dengan menggunakan natural symbol dan privat symbol, Puisi-puisi SDD mayoritas menggambarkan dunia misteri kesunyian yang dihadirkan sebagai sesuatu yang tidak ada( flow chart) yang ada hanya degup, suara, warna, dan ide hadir seperti sebuah bayang putih yang membaur dan terasa jauh. Dalam bingkai bahasa itu, di dalam puisi-puis SDD dapat dilacak jejak mistisime Jawa yang mempersoalkan renungan awal-akhir (sangkan-paran), kefanaan, kematian dan keheningan khas Jawa (sonya ruri).
\end{abstract}

Kata kunci: puisi, piranti bahasa, mistisime Jawa.

\section{Abstract}

This study is an effort to analyse language instrument and also to interpret and explore the socio-cultural context of Sapardi Djoko Damono (SDD) 's poetries which are compiled in Hujan Bulan Juni poetries collections published by Gramedia Pustaka Utama in June 2013. The initial foundation of this study is stylistic by focusing to discover the literature aspects such as sounds, words, symbols, images and figure of speeches. In this study, SDD's poetries appears dominated by the atmosphere of distress, silence and impermanence based on cacophony power, paradox style which contrasts words with two different meanings, presenting images which build mysteries spaces to the readers. The words were precisely selected using natural and private symbols. SDD's poetries mostly describe the calmness of mystery world which is presented by something that is not exist (flow chart), and there are only the sound of gulps, voices, colours and ideas that appear like a white shadow that assimilated and felt far away. In that language frame, inside SDD's poetries, Javanese mysticism traces that question the beginning-end afterthoughts (sangkan-paran), impermanence, death and typical Javanese silence (sonya ruri) can be tracked.

Keywords: poetry, language instrument, Javanese mysticism 


\section{Pendahuluan}

Penyair senantiasa berurusan dengan dunia dalam, menggarap makna dengan perenungan. Prestasi seorang penyair diukur berdasarkan mendalamnya makna yang sanggup diserap dan diendapkannya, dan persoalan persoalan pertama bagi penyair adalah bagaimana menyampaikan dunia dalam kepada dunia luar, dunia bersama, dunia publik yang memiliki banyak variabel dan kemungkinan.

Dalam upaya menyampaikan dunia dalam kepada dunia luar ini penyair memerlukan bahasa. Persoalan penyair dengan bahasa adalah bagaimana penyair memilih corak bahasa, memilih materi bahasa berupa kata, serta menata kata untuk mewadahi imajinasi dan perenungannya berkait dengan kontek sosial budaya serta motifnya dalam berkarya.

Bidang garapan stilistika adalah bahasa yang dipakai dalam konteks tertentu dan dalam ragam bahasa tertentu. Istilah stilistika merujuk pada pengertian tentang stile, yaitu kajian terhadap wujud performasi kebahasaan, khususnya yang terdapat dalam teks-teks kesastraan (Leech and Short, 2007: 11). Analisis stilistika biasanya dimaksudkan untuk menerangkan hubungan bahasa dengan fungsi artistik dan maknanya sekaligus mengeksploitasi kreativitas penggunaan bahasa (Wareen \& Wellek, 1989:180; Simpson, 2004: 3).. karena itu kajian stilistika membawa pembaca ke arah pemahaman yang lebih baik tentang bagaimana bahasa dapat dikreasikan dan didayakan sedemikian rupa, mungkin lewat penyimpangan, pengulangan, pemekaran, penekanan dan penciptaan ungkapan baru yang membuat komunikasi bahasa menjadi lebih segar dan efektif.

Bahasa atau kata menjadi hal yang sangat elementer dalam penciptaan puisi. Nasib seorang penyair dipertaruhkan ketika saat pertama kali ia mencari-cari dan memaknai kata, ia tidak punya pilihan lain kecuali menguasai bahasa karena kekuatan kata atau bahasa dalam puisi ibarat urat nadi dari puisi itu sendiri. Tidak mengherankan apabila penyair besar Chairil Anwar pernah berucap: "Prosaku, puisiku juga, dalamnya tiap kata akan kugali-korek sedalam-dalamnya hingga ke kernwoord ke kernbeeld"'1, juga Amir Hamzah Sang Raja Penyair Pujangga Baru mengingatkan penyair-penyair muda di zamannya: "Jangan terlalu lekas melompat-lompat dari sebuah tempat ke tempat yang lain, dan jangan memakai kata yang belum resap sampai arti, intinya ke dalam tulang sungsum." 22

Kata dalam puisi mempunyai kedudukan yang paradoksal. Di satu sisi selalu dibebani dan dikungkung untuk menyampaikan pengertian atau makna, tetapi di sisi lain dalam puisi kata menjungkir-balikkan pengertian yang umum yang disandang oleh kata itu 1 Surat Chairil Anwar kepada H.B Yasiin. PDS H.B Yasiin

$2 \quad{ }^{2}$ Pernyataan ini dapat ditemukan dalam surat Amir Hamzah kepada Armijn Pane. PDS H.B Yasiin. 
sendiri. Pada sisi ini penyair menggempur, memperhitungkan, bahkan mengingkari semantik yang sudah lazim diemban oleh kata tersebut. Bagi penyair mengolah kata adalah pengembaraan tanpa akhir, suatu saat ia sampai dan berdiam pada sebuah titik, di kesempatan lain ia memporak-porandakan titik itu untuk mencari titik-titik yang lain. Karena pengembaraan inilah bahasa dan kata senantiasa menjadi penyebab sejarah puisi yang tidak pernah tamat dari hiruk-pikuk pencarian dan pencapaian estetis.

Berkaitan dengan bahasa (kata) itu dalam tulisan ringkas ini akan coba dikupas warna estetis bahasa puisi penyair Sapardi Djoko Damono dan kosmologi mistisime Jawa sebagai wawasan estetik yang mewarnai kumpulan puisi Hujan Bulan Juni Sepilihan Sajak, yang memuat 102 sajak yang diterbitkan Penerbit PT Gramedia Pustaka Utama, Juni 2013. Tentu saja karena berbagai keterbatasan tidak semua dari sajak-sajak itu yang akan dianalisis dengan sedikit harapan, semoga yang sebagian kecil ini dapat memberikan gambaran bagaimana warna estetika puisi sekaligus wawasan estetika penyair Sapardi Djoko Damono.

\section{Kajian Teori dan Metodologi}

Secara harfiah stilistika berasal dari bahasa Inggris stylistic yang berarti studi mengenai gaya bahasa. Sedangkan secara istilah, stilistika adalah ilmu yang meneliti penggunaan bahasa dan gaya bahasa di dalam karya sastra (Abrams, 1979: 165; Satoto, 2012: 36). Lebih lanjut dijelaskan oleh Leech dan Short (dalam Al-Maruif, 2012: 11) bahawa stilistika adalah studi tentang wujud performansi kebahasaan khususnya yang terdapat dalam karya sastra yang menganalisis hubungan antara bahasa dengan fungsi artisitiknya beserta maknanya.

Dalam perkembangannya, stilistika modern menunjukkan adanya perkembangan dalam dua sisi. Di satu sisi memfokuskan diri pada analisis penggunaan aspek bahasa dalam sebuah teks untuk mencari keindahan dari teks tersebut. Di sisi yang lain, kajian stilistika juga memberhatikan pada bidang lain di luar wilayah linguistik, seperti misalnya sosiolinguistik, studi gender, kultur, dan lain-lain yang melibatkan konteks. Sisi yang pertama disebut kelompok tekstualis, dan sisi kedua disebut kontekstualis (Bradfod, 2005; Zyneger 201; dan Nurgiyantoro, 2014)

Kajian stilistika tekstualis membawa pandangan mahzab Formalisme Rusia dan New Criticism yang memfokuskan analisisnya hanya pada teks dan tidak mengaitkannya dengan teks-teks lain di luar teks yang bersangkutan (Nurgiyantoro, 2014:81). Dengan kata lain kajian stilistika tekstualis berkutat pada unsur-unsur teks pusi atau prosa di dalam teks itu saja tanpa mengaitkannya dengan "teks- teks" yang lain. Karya sastra melulu dipandang sebagai sesuatu yang bersifat otonom yang berdiri sendiri dengan ciri 
khasnya sendiri.

Dalam kajian teksttualis ini, seorang pengkaji aliran ini senantiasa membatasi diri hanya untuk membahas masalah-masalah gaya teks, yang meliputi aspek leksikal, aspek struktur, majas analis bunyi, kata, penggunaan simbol tanpa menelisik lenbih jauh ke teks-teks lain di luar unsur otonom teks yang dibahas, baik itu berupa teks pusi atau prosa.

Sedangkan kajian stilistika konstektualis memandang bagaimana sebuah bahasa tidak dapat dilepaskan dari konteks karena konteks akan memengaruhi bentuk bahasa yang dipakai. Teks puisi misalnya, sebenarnya merupakan konstruk sosial, bagian dari tradisi sosial, budaya bahkan juga politik (Nurgiyantoro, 2014; Satoto, 2012; AlMal'aruf, 2012).

Dengan kata lain, dalam sitilistika kontekstualis memandang bahwa selain teks puisi yang dibahas, terdapat pula teks-teks lain yang merupakan konteks dari teks puisi tersebut. Apabila seorang pengkaji ingin memeroleh pemahaman yang lebih dalam dan menukik, maka perlu pula mengkaitkannya dengan konteks dari teks puisi tersebut. Pengaruh konteks dianggap memiliki pengaruh besar dalam membentuk gaya penuturan. Di antara berbagai faktor konteks itu yang dianggap cukup signifikan adalah faktor sosiokultural, dan faktor kultural yang dimiliki oleh masyarakat dimana pengarang adalah bagian darinya.
Kajian dalam tulisan ini berdasarkan pada pandangan bahwa analisis gaya pasti terpengaruh dan dipengaruhi oleh kondisi kultur masyarakat dan pengarang. Muatan makna yang terkandung dibalik keindahan bahasa akan dipengaruhi bahkan terkadang ditentukan oleh kosmologi budaya, nilai-nilai, norma, konvensi sosial budaya atau bahkan ideologi pengguna bahasa itu. Singkat kata, kajian dalam tulisan ini mengakui pandangan bahwa stilistika dapat dikaji dengan pendekatan kultural (Zyngier, 2001)

Metode dalam tulisan ini menggunakan metode kualitatif deskriptif, yakni prosedur penelitian yang menghasilkan data deskriptif berupa kata-kata atau kalimat tertulis yang terdapat dalam kumpulan puisi Hujan Bulan Juni karya SDD yang merupakan sumber data penelitian. Selanjutnya juga dideskripsikan pandangan-pandangan mistisisme Jawa yang terdapat dalam kumpulan puisi tersebut.

Tahapan pengkajian dalam tulisan ini dideskripsikan sebagai berikut. Pertama, penulis mengkaji terlebih dulu aspek stilistik berupa ragam bunyi, kata, simbol, dan majas yang terdapat dalam puisi Hujan Bulan Juni karya SDD.. Kedua, dilakukan pengkajian dengan melihat latar belakang sosio historis dan ideologis budaya pengarangnya, dan ketiga, pengungkapan makna stilistika yang berhubungan secara konstektual dengan ideologi kultur pengarangnya berdasarkan tanggapan penulis (peneliti) sebagai pembaca kri- 
tis.

\section{Pembahasan}

Piranti Bahasa Puisi SDD: dari Ragam

Bunyi, Simbol dan Imaji

Perbedaan puisi dengan teks sastra yang lain adalah puisi dalam berkomunikasi dengan pembaca memilih cara berkomunikasi dengan bahasa simbolik, hal ini berarti komunikasi dalam puisi memilih jalan melingkar. Dengan memilih jalan melingkar puisi menuntut publik pembaca yang kualitatif, pembaca-pembaca intensif yang bersedia membuka diri terhadap simbolisasi bahasa yang dibangun dalam sebuah komunikasi literer.

Berhadapan dengan sajak-sajak Sapardi Djoko Damono (SDD), pembaca akan senatiasa dipaksa untuk mencoba menelusuri bahasa personal/individual sebagai kerja kepenyairan dengan keniscayaan untuk berkomunikasi. Sajak-sajak SDD melalui pilihan-pilihan kata, frase, atau kalimatnya mampu memberikan gambaran kesan mental tertentu yang sebenarnya merupakan reproduksi dalam pikiran mengenai perasaan yang dihasilkan oleh persepsi yang bisa jadi berupa fisik, metafisik, mistis dan psikologis.

Dalam sajak pertama berjudul Tangan Waktu misalnya, pembaca digiring pada sebuah gambaran dan suasana kematian yang ditekankan berulang-ulang yang akibatnya pembaca menjadi terasa disesaki dengan kesadaran bahwa waktu merupakan penanda dari sebuah kefanaan. Kesadaran yang tidak diucapkan tanpa kesan meratap-ratap namun sebuah kesadaran yang hening, syahdu dan bersahaja. Berikut dikutipkan puisi tersebut secara utuh:

\section{Tangan Waktu}

selalu terulur ia lewat jendela

yang panjang dan menakutkan selagi engkau bekerja, atau mimpi pun tapa berkata suatu apa

bila saja kautanya: mau apa berarti terlalu jauh kau sudah terbawa sebelum sungguh menjadi sadar bahwa sudah terlanjur terlantar

belum pernah ia minta izin memutar jarum-jarum tua yang segera tergesa-gesa saja berdetak tanpa menoleh walau kuseru

selalu terulur ia lewat jendela yang makin keras dalam pengalaman mengarah padamu tambah tak tahu memegang leher bajumu

Pilihan kata "terulur" pada permulaan sajak yang kemudian direpetisikan pada bait terakhir sangat menarik karena dengan repetisi ini penyair berusaha menekankan persoalan kematian sebagai persoalan dasar yang ingin diungkapkan. Kata "terulur" mengasosiasikan kematian sebagai sebuah kekuatan tak ter- 
lawan sekaligus sebuah keharusan yang mesti dilakoni. Pilihan kata "memutar jarum-jarum tua" merupakan pemilihan simbol yang tepat untuk menggambarkan seorang yang rapuh dan lemah yang menunggu panggilan maut. Dan baris terakhir yang berbunyi: "memegang leher bajumu" mempertegas betapa berkuasanya kematian. "memegang leher baju" yang dalam Bahasa Jawa diistilahkan dengan kata cengkiwing membentuk sebuah gambaran bahwa tangan yang mencengkiwing merupakan kondisi kekuatan yang superior atau berkuasa, dan yang “dicengkiwing” merupakan obyek yang lemah, tak berdaya dan dikuasai. Dalam kontek ini yang mencengkiwing adalah maut atau kematian, sedangkan pihak yang dicengkiwing adalah manusia yang tak berdaya dalam tangan maut atau kematian.

Sajak-sajak SDD dalam kumpulan puisi Hujan Bulan Juni ini mayoritas menghadirkan suasana-suasana yang hening, syahdu, suram, haru dan pilu. Suasana-suasana itu muncul karena penyair mengusung tema-tema berat seperti kefanaan, alienasi (keterasingan), anxiety, kematian, kekalahan, ketragisan, serta renungan-renungan tentang asal muasal kehidupan (Jw: sangkan paraning dumadi).

Untuk menciptakan suasana-suasana ketertekanan, hening, syahdu, suram, haru dan pilu tersebut, SDD banyak memanfaatkan bunyi-bunyi kata cacophony yang banyak didominasi dengan konsonanan berat seperti konsonan k,h,m, ng p, t,s,r, ${ }^{33}$. Seperti terlihat pada baris puisi: kutanggalkan mantel serta topiku yang tua/ ketika daun penanggalan gugur/ lewat tengah malam. Kemudian kuhitung/ hutang-hutangku pada-Mu...(Sajak Desember).

Demikian juga larik-larik dalam sajak berjudul Tengah Hari memanfaatkan cacophony untuk menghadirkan imaji tentang kekalahan dan ketakberdayaan: jalanan mengombak tanpa suara/aku pun kau panggil ketika mereka sudah pulang/sehabis huru haralada yang mendadak rembang, ada yang bergegas petang/. Sedang untuk mengimajikan keterasingan (alienasi) sekaligus kefanaan, SDD menulis larik: sementara kita saling berbisik/ untuk lebih lama tinggal/ pada debu, cinta yang tinggal berupa/ bunga kertas dan lintasan angka-angka/ ..../ (Sementara Kita Saling Berbisik)

Selain memanfaatkan bunyi kata cacophony, SDD juga memanfaatkan gaya paradaksol dengan mempertentangkan kata yang mempunyai dua sifat berbeda seperti yang diperlihatkan pada larik-larik sajak Saat Sebelum Berangkat berikut ini: Imengapa kita masih juga bercakap/hari hampir gelap .../ di ruang semakin maya, dunia purnama/... Kata 'bercakap' yang mengacu pada

$3 \quad{ }^{3}$ Ragam bunyi cacophony merupakan ragam bunyi yang dapat memberikan kesan/suasana ketertekanan, kesedihan, kesepian, yang ditandai dengan dominasi bunyi konsonan. Lawan dari cacophony adalah bunyi euphony yang mengesankan vitalitas, keriangan, semangat atau gerak. Euphony didominasi dengan bunyi-bunyi vokal. 
sesuatu yang bersemangat, begelora dan penuh vitalitas hidup digabungkan sekaligus dilawankan dengan kata'gelap' yang merujuk pada suatu hal yang muram dan nglangut. Sedangkan sesuatu yang yang fana di ruang semakin maya diparadoksalkan dengan dengan sesuatu yang terang yakni dunia purnama.

Tema-tema sajak yang diangkat penyair SDD berangkat dari pemikiran dan persoalan filosofis yang berputar pada "pencarian" eksistensi manusia dan hal-hal yang bersifat kontemplatif. Melalui sajak-sajaknya SDD menampilkan keberadaan manusia (aku lirik) yang selalu mempermasalahkan realitas dirinya maupun realitas di luar dirinya sebagai suatu eksistensi dengan berbagai kemungkinan-kemungkinan. Berbagai kemungkinan-kemungkinan itu membuat sajak-sajak SDD banyak yang mencerminkan sosok manusia, sosok aku lirik sebagai mahluk yang tidak mantap, mahluk yang an unstettled animal.

Persoalan tentang hakekat manusia diperlihatkan dengan padat tapi indah dan tegas pada sajak Narcissus berikut ini: seperti juga aku: namumu siapa, bukan/pandangmu hening di permukaan telaga dan rindumu dalam/tetapi jangan saja kita bercinta/ jangan saja aku mencapaimu dan kau padaku menjelma/ atau tunggu sampai angin melepaskan selembar daun/dan jatuh di telaga: pandangmu berpendar, bukan?/cemaskah aku kalau nanti air hening kembali?/cemaskah aku kalau gugur daun demi daun lagi?/.

Dalam puisi ini SDD memperlihatkan sosok manusia yang tidak dapat melepaskan diri dari berbagai kemungkinan-kemungkinan justru karena manusia tidak mampu menghayati dirinya sebagai suatu hakikat. Manusia yang tidak pernah berhenti dalam ke-kinian, setiap ia mencoba ke luar dari ke-kiniannya itu senantiasa ditransedensikannya sendiri ke 'yang nanti', 'yang kemudian' atau 'yang akan datang', ke dalam sesuatu yang belum maujud sebagai realitas. Jadilah manusia menjadi mahluk yang senantiasa "membelum" atau "menjadi", mahluk yang terus-menerus terlibat dalam perancangan masa depannya karena terperosok kepada kemampuannya sendiri dalam mengandaikan segala kemungkinan dan realitas, yang menurut baris puisi SDD di atas dikatakan dalam kalimat retoris ...cemaskah aku kalau nanti air hening kembali? Cemaskah aku kalau gugur daun demi daun lagi?.

SDD dengan mengusung tema-tema kontemplatif menghadirkan pada diri pembacanya imaji yang membangun ruang-ruang misteri yang sarat dengan suasana sunyi dan asing. Ruang-ruang misteri dan dunia asing itu hadir akibat pemilihan kata yang dengan cermat dipilih dengan menggunakan natural symbol dan privat symbol ${ }^{44}$ untuk mem-

$4 \quad{ }^{4}$ Natural symbol adalah simbol yang menggunakan realita alam untuk melukiskan sesuatu. Privat symbol adalah simbol yang menjadi ciri atau "trade mark" penyair tertentu. 
bangun nuansa-nuansa yang diinginkan penyairnya. Seperti terlihat pada larik: kabut yang likat dan kabut yang pupur/lekat dan gerimis pada tiang-tiang jembatan/ matahari menggeliat dan kembali gugur/ tak lagi dilangit! Berpusing di pedih lautan (Kartu Pos Bergambar: Jembatan Golden Gate, San Fransisco).

Atau pada baris sajak yang lain: tak ada yang lebih tabah/dari hujan bulan juni/ dirahasiakannya rintik rindunya/ kepada pohon berbunga itu/ tak ada yang lebih bijak/ dari hujan bulan juni/dihapusnya jejak-jejak kakinya/ yang ragu-ragu di jalan itu/ tak ada yang lebih arif/ dari hujan bulan juni/ dibiarkannya yang terucapkan/diserap akar pohon bunga itu/(Hujan Bulan Juni). Juga pada sajak yang sangat popular dan digandrungi anak muda berjudul Aku Ingin berikut ini: Aku ingin mencintaimu dengan sederhana:/ dengan kata yang tak sempat diucapkan/ kayu kepada api yang menjadikannya abu/ Aku ingin mencintaimu dengan sederhana:/ dengan isyarat yang tak sempat disampaikan/ awan kepada hujan yang menjadikannya tiada.

Ruang-ruang misteri yang penuh dengan suasana sunyi dan asing yang dihadirkan SDD tersebut menurut Afrizal Malna ${ }^{55}$ disebut sebagai "metode penjauhan" yang menciptakan pesona di mana alienasi yang dimunculkan tidak menghasilkan represi, tetapi justu menghasilkan keintiman. $5 \quad{ }^{5}$ Lihat Afrizal Malna, Sesuatu Indonesia. Bentang, Jogjakarta. 2000 hal. 32
Puisi-puisi SDD mayoritas menggambarkan dunia misteri kesunyian yang dihadirkan sebagai sesuatu yang tidak ada flow chart: yang ada hanya degup, suara dan warna, dan ide hadir seperti sebuah bayang putih yang membaur dan terasa jauh. Akibat logis dari dunia asing dan ruang misteri itu puisi-puisi SDD cenderung tampil sebagai puisi prismatis yang membuka peluang besar untuk ditafsiri. Puisi menjadi sebuah medan teks yang memiliki kesatuan antara pembaca dan penulisnya yang masing-masing memiliki kedaulatannya sendiri-sendiri, dan di atas kedaulatanya itu pembaca dan penyair membangun lorong referensialnya masing-masing.

\section{Mistisime Jawa}

Dalam sajak-sajak yang terdapat dalam buku kumpulan puisi Hujan Bulan Juni terlihat sumber inspirasi SDD bersumber pada satu hal, yakni dari kosmologi kebatinan (mistik) Jawa yang bermuara pada pertanyaan tentang Awal dan Akhir, yang dalam konsep Jawa dikenal sebagai "ngelmu sangkan-paran" (Sangkan Paraning Dumadi). Dan jawaban dari pertanyaan Awal dan Akhir ini dapat direnungkan melalu konsep mistisisme Jawa yang menggali sesuatu dari yang "sunyi" atau "ning"66.

$6 \quad{ }^{6}$ Ciptoprawiro, Abdullah. Tanpa tahun. Filsaat Jawa: Manusia Dalam Tiga Dimensi Kehidupan. Yogyakarta: Proyek Javanologi. Dalam buku ini Ciptoprawiro menjelaskan bahwa mistik Jawa adalah suatu wawasan hidup yang dipilih dan dihayati tanpa melalui penyelidikan ilmiah tapi hanya didasarkan pada kecocokan rasa, pencarian dengan kekuatan sendiri 
Mistik Jawa sering pula dikenal dengan nama ngelmu ke-Jawen (filsafat Jawa/ ke-Jawen). Berlainan dengan konsep dan pengertian tentang filsafat Barat, filsaat keJawen bertujuan agar rohani manusia dapat memahami hal-hal yang ada di balik dunia yang nampak, sehingga manusia dapat meraih nilai-nilai yang lebih tinggi dari nilai-nilai moral. Karena itu filsat Jawa tidak disebut dengan "ilmu" tetapi disebut sebagai "ngelmu"77. Ngelmu ke-Jawen tidak membatasi diri pada nalar dan logika, melainkan mencari kemungkinan-kemungkinan lain dalam usaha penganalisisannya selain nalar juga melalui intuisi dan rasa.

Filsaat Jawa atau ngelmu ke-Jawen, tidak menanyakan "apakah" manusia itu, namun menanyakan: "dari mana" dan "ke mana" manusia, yang dalam konsep Jawa disebut pengetahuan tentang sangkan paraning dumadi (dari mana asal muasal). Konsep sangkan paraning dumadi ini diterjemahkan oleh Tanpoaran ${ }^{88}$ sebagai metafisika atau filsafat Jawa tentang "Ada” yang merupakan perenungan metafisi-religius tentang suatu keberadaan, asal dan tujuan hidup atau "dari mana dan ke mana hidup itu". Pencarian ini akan berkesimpulan bahwa Tuhan merupakan tujuan sangkan paraning dumadi, awal tentang hakikat segala wujud, yang bersifat mendasar dan mendalam (hal.7)

$7 \quad{ }^{7}$ Hadiwiyono,Harun. 1985. Konsepsi Manusia dalam Konsepsi Kebatinan Jawa. Jakarta: Sinar Harapan.

$8 \quad{ }^{8}$ Tanpoaran, Tanpa tahun. Sangkan Paraning Dumadi.Surabaya: Yayasan Joyoboyo, hal. 31 dan hidup berarti berasal dari Tuhan dan akhir berarti mulih mulanira ${ }^{99}$ (pulang pada asalnya).

Dengan pemahaman dan kesadaran tentang ngelmu sangkan paran ini, orang Jawa memiliki kesadaran bahwa hakekat hidup adalah perjalanan "pulang" kembali ke asal sebab hidup adalah persinggahan sementara, yang dalam Bahasa Jawa dikatakan sebagi urip iku mung mampir ngombe (hidup itu hanyalah sekedar singgah untuk minum). Problema hidup mencari kesempurnaan kembali ke asalnya ini terlukis dengan indah dalam Serat Suluk Wujil bait 5 yang mencakup semua pertanyaan tentang hakikat hidup, kuasa, Yang Tunggal, Yang Ada dan yang tak $\operatorname{ada}^{1010}$.

Konsep ngelmu sangkan paraning $d u$ madi, ini dapat ditelusuri pada larik sajak-sa-

$9 \quad{ }^{9}$ Ciptoprawiro, tanpa tahun hal 28.

$10 \quad{ }^{10}$ Serat Suluk Wujil adakah serat suluk yang menggambarkan masa peralihan dari jaman Jawa Hindu ke Jawa Islam. Suluk ini menceritakan seorang Brahmana bernama Wujil yang menjadi murid dari Sunan Bonang dan kemudian memeluk Islam. Serat ini disebut juga dengan Serat Ajaran Rahasia Sunan Bonang yang berisi filsafat dan pandangan dalam mencari kesempurnaan hidup, seperti tergambar dari kutipan berikut:

"Ya marma lunga ngikis ing wengi

Angulati sarahsaning tunggal

Sampurnaning langkah kabeh

Sing pandita sunduning

Angulati sarining urip

Wekasing jati-wenang

Wekasing lor-kidul

Suruping raditya wulan

Reming netra kalawan suruping pati

Wekasing ana-ora" 
jak Sehabis Mengantar Jenazah berikut ini: /masih adakah yang akan kau tanyakan/ tentang hal itu?/ hujan pun sudah selesai/ sewaktu tertimbun sebuah dunia yang tak habisnya bercakap/di bawah bunga-bunga menua, matahari yang senjal pulanglah dengan payung di tangan tertutup/ anakanak kembali bermain di jalanan basah/seperti dalam mimpi kuda-kuda meringkik di bukit yang jauh/ ...../alangkah angkuhnya pintu yang akan menerima kita/ seluruhnya, seluruhnya kecuali kenangan/ pada sebuah goa yang menjadi sepi tiba-tibal.

Dalam larik-larik sajak ini nampak SDD sebagai orang Jawa ${ }^{1111}$ menghayati benar bahwa kematian pada dasarnya adalah perjalanan mulih mula nira, perjalanan pulang kembali ke asal, ke kampung halaman yang hakiki. Yang dalam bahasa SDD dikatakan sebagai "pulanglah dengan payung di tangan". Konsep tentang sangkan paran ini terdapat juga dalam larik-larik sajak yang lain berikut ini: ...../tiba-tiba angin kemarau/ debu dan sobek-sobekan kertas/ (barangkali surat kelahiran, barangkali/ lelayu barangkali) tiba-tiba saja/ sempurna lingkaran itu/ tiba-tiba kaupun menjelma sunyi/ ruang kosong antara bumi/ dan matahari, sebelum tikungan/ ada yang bertanyal "tapi kau/pergi ke mana saudara?"'/...../(Iring-iringan di Bawah Matahari).

Dalam larik di atas nampak bahwa ke-

$11 \quad$ "Sapardi Djoko Damono lahir di Solo dan menghabiskan masa remajanya di kota tersebut hidupan dan kematian adalah mata rantai yang sempurna. Dalam larik ini "surat kelahiran" yang mengisyaratkan awal mula digandengkan dengan "lelayu". Kata "lelayu dalam bahasa Jawa berarti kabar kematian, atau kematian itu sendiri. Keduanya merupakan rangkaian dari awal dan akhir, sangkan paraning dumadi. Dalam bahasa puisi SDD dikatakan sebagai sebuah lingkaran yang sempurna, "barangkali surat kelahiran, barangkali/ lelayu, barangkali...) tiba-tiba saja/ sempurna lingkaran itu. Konsep sangkan paraning dumadi, renungan tentang hakekat hidup dan kematian khas Jawa ini juga dapat ditemukan lagi pada sajak-sajak Berjalan ke barat Waktu Pagi Hari, Cahaya Bulan Tengah Malam, Percakapan Malam Hujan, Variasi Pada Suatu Pagi, Pertemuan, Sonet: Y, Muara, Sehabis Suara Gemuruh, Pada Suatu Pagi Hari, Maut dan Terbangnya Burung.

Selain konsep sangkan paraning $d u$ madi, dalam sajak-sajak SDD juga ditemukan konsep meditatif khas Jawa yang disebut mahas ing ngasepi, yang bisa diterjemahkan dalam Bahasa Indonesia sebagai "merenungkan diri dalam sunyi”. Proses ini muncul setelah seseorang menyadari, memahami, tentang asal mulanya (sangkan paran). Dalam proses ini seorang idividu Jawa dalam laku mistis mencari kesempurnaan dengan masuk dalam diri pribadinya merenungkan hal-hal tentang Tuhan, insan dan alam secara tekun dan sunggguh-sungguh. 
Proses meditasi ini disebut sebagai penghayatan ingsun atau pribadi dalam diri manusia. Dalam laku ini, seseorang menceburkan diri masuk dalam "kesunyian" diri (konsep Jawa: ning) pribadinya dan melihat dirinya dan lingkungan hidupnya dalam dimensi yang lebih tinggi. Dalam kesunyian meditasi khas Jawa ini seorang manusia Jawa akan menghayati kesadaran pribadi dan terbukalah hubungan dengan Tuhan, alam dan lingkungan gaib, yang semuanya tercapai bila sudah sampai pada "keheningan" atau "kesunyian" yang dikenal dengan istilah sonya ruri ${ }^{1212}$.

Dalam "kesunyian" atau sonya ruri ini manusia dapat menghayati kekuatan-kekuatan alam, dirinya dan lingkungan batinnya. Ia berhasil mencapai kesatuan dan terjadi spiritualisasi dan dapat melepaskan nafsu-nasu pribadi, melepaskan dari dari dunia material dan menyadari kefanaanya. Timbul suatu rasa bersatu kembali dengan alam sejati menuju gerak pulang yang disebut dengan $\mathrm{ra}$ sajati $^{1313}$. Rahmat Subagya ${ }^{1414}$ menjelaskan proses itu sebagai tipe kosmis di mana terdapat hasrat untuk meleburkan diri ke dalam daya kosmos universal dan memberhentikan individualisasi dan selanjutnya bereksistensi secara transeden sebagai kesatuan mutlak mencapai kebahagiaan tertinggi.

$12{ }^{12}$ Harun Hadiwiyono. 1982.Konsepsi Tentang Manusia dalam Konsepsi Kebatinan Jawa. Jakarta: Sinar Harapan. Hal 43.

$13 \quad{ }^{13}$ ibid hal 48

$14{ }^{14}$ Kepercayaan, Kebatinan,

Kerohanian dan Agama. 1976 hal 50-51.
Keseluruhan proses meditasi khas Jawa ini dalam kosmologi budaya Jawa dilukiskan dalam cerita pewayangan Dewa Ruci. Tokoh Bima sebagai lambang manusia bertemu dengan ingsun atau pribadinya yang dilambangkan dengan tokoh Dewa Ruci yang merupakan replica dari Bima dalam wujud yang kecil. Selanjutnya Bima yang bertubuh tinggi besar masuk dalam lobang telinga Dewa Ruci yang isiknya jauh lebih kecil dari Bima. Ini merupakan gambaran dilakukannya proses meditasi masuk dalam kesunyian atau sonya ruri. Bima manunggal dengan Dewa Ruci, "aku” menjadi "ingsun”.

Oleh SDD kisah mistis Dewa Ruci ini diangkat dalam sajak berjudul Telinga berikut ini: "Masuklah ke telingaku”, bujuknya./ Gila:/ ia digoda masuk ke telinganya sendiri/ agar bisa mendengar apapun/ secara terperinci ---setiap kata, setiap huruf/ bahkan letupan dan desis yang menciptakan suaral “masuklah”, bujuknyal Gila! Hanya agar bisa menafsirkan sebaiknyal apapun yang dibisikkannya/ kepada diri sendiri.

Melalui sajak Telinga ini SDD menghadikan kembali lakon Dewa Ruci sekaligus mengusung kembali konsep meditasi Jawa yang menekankan pada kesunyian atau Sonya ruri. Dalam hening Sonya ruri ini sebenarnya seseorang dapat mendengar dan memperoleh banyak hal sampai sedetil-detilnya. Dalam suasana "kesunyian" Jawa ini tidak saja sesorang menyadari keberadaan yang badani dan kasar (material) namun, juga mempero- 
leh pemahaman, pengalaman, kesadaran dan kehadiran akan sesuatu yang halus (immaterial) bahkan yang gaib. Yang dalam bahasa puisi SDD di atas dinyatakan sebagai agar bisa mendengar apapun secara terperinci setiap kata setiap huruf bahkan letupan dan desis yang menciptakan suara.

Melalui larik sajak yang lain bahkan dikatakan oleh SDD bahwa "kesunyian", keheningan atau Sonya ruri sebenarnya menyimpan berbagai kemungkinan. Dalam kesunyian meditasi Jawa sebenarnya tersimpan bising, hiruk pikuk atau keramaian yang bergemuruh dalam proses pencarian tentang hakekat diri manusia. Ini digambarkan oleh SDD: bagi yang masih percaya pada kata:/ diam pusat gejolaknya, padam inti kobarnya--/ .../ apakah yang kita dapatkan di luar kata:/ taman bunga? ruang angkasa?/ di taman, begitu banyak yang tak tersampaikan/di angkasa, begitu hakiki makna kehdidupan/ ..../ (Sajak-sajak Empat Seuntai)

Proses meditasi sebagai sarana mencari hakekat tentang aku atau "ingsun"dalam kesunyian membutuhkan proses panjang dan berat. Manusia harus mampu mengalahkan dirinya sendiri. Harus mampu menguasai nafsu-nafsunya, menjaga hati dan perasaannya, menghilangkan rasa pamrih dalam diri dan menonjolkan kepasrahan dan ketakkuasaannya dalam menghadapi "kenyataan" lain yang non material (Kasunyatan). Yang dalam bahasa Jawa laku atau proses ini dikatakan sebagai ngekes panca driya, nutupi babahan hawa sanga: menguasai dan mengatur panca indra, menutupi sembilan lobang di tubuh sebagai simbol jalan keluarnya nafsu". Proses ini dengan indah ditampilkan oleh SDD dalam puisinya berjudul Suara. Berikut dinukilkan secara lengkap puisi tersebut:

Suara

Aku tak mengenal lagi suaraku. Kau seperti menangis, kata-Mu.

Engkau mungkin mendengar sesuatu, tapi itu bukan suara$\mathrm{ku}, \mathrm{aku}$ mendengar sesuatu tapi mugkin itu bukan suara-Mu. Suara siapa,

aku belum pernah mendengar sebelumnya; merapatlah kemari.

Seperti ada yang asing, yang mengajak bicara padaku, menghitung

tahun-tahunku. Aku merapat pada-Mu.

Ini, kubisikkan sesuatu pada-Mu; nah, Kau dengar sekarang, itu bukan suaraku. Ada yang telah berbisik mengenai hari itu.

Kau takut, Tanya-Mu. Aku merapat pada-Mu. Suara siapa

Gerangan telah terucap lewat mulut serta dua belah mataku.

Puncak dalam "ning" atau Sonya ruri ini hadir sebuah penghayatan di mana seseorang hanya sebagai pletikan atau sempalan yang harus pulang ke dalam titik pangkalnya lagi. Individu tersebut secara rohaniah mulai berhasil menanggalkan balutan-balutan (yang bersifat material) yang menyelubungi jiwanya sehingga ia lepas dari kungkungan alam lahir dan menguasainya sehingga menyadari wujudnya asli, polos dan kosong. Dan pun- 
caknya sampailah kesadaran akan hadirnya Tuhan di hatinya, Tuhan dan dirinya seakan-akan serupa tapi tak sama. Inilah yang mahsyur dikenal dengan istilah manunggaling Kawula Gusti, bersatunya kawula (hamba) dengan Gusti (Tuhannya). Penghayatan manunggaling kawula gusti ini dapat disejajarkan dengan konsep wihdatul wujud dalam khazanah sufistik Islam atau Atman-Brahman dalam konsep Hindu.

Dengan tercapainya manunggaling kawula gusti, tercapailah puncak mistisime Jawa, merasa dirinya bersatu dengan Tuhan, muncul penghayatan antara yang mencintai dan dicintai telah menjadi satu; yang disadari hanya satu wujud walaupun sebenarnya ada dua wujud. Yang disadari hanyalah wujud Tuhan. Ketika sampai di ambang pintu penghayatan penyatuan ini seringkali muncul ucapan-ucapan ganjil yang isinya memuja Tuhan dan melukiskan keindahan penyatuan denganNya, dalam istilah tasawuf disebut sebagai syatahat (theopatical tammering) ${ }^{1515}$.

$15 \quad{ }^{15}$ Dalam mistis Jawa, ucapan ganjil untuk melukiskan bersatunya Tuhan dengan hambanya ini misalnya: curiga manjing warangka, warangka manjing curiga (keris yang masuk dalam rangka (sarungnya), sarung yang masuk dalam kerisnya); kodok angemuli leng, leng angemuli kodok (katak yang menyelubungi liangnya, liang yang menyelubungi kataknya); jagad ginelung, jagat kawedhar (semesta yang dimasukkan dalam jiwa, jiwa yang masuk dalam semesta), dll. Dalam dunia sufistik Islam mahsyur ucapan syatahat dari tokoh sufi : Al Halaj: Ana al-haq (aku adalah Kebenaran). Atau ucapani Abu Jazid: “Aku ingin untuk tidak mengingini. Aku tidak ingin dari
Dalam puisi-puisi SDD jejak konsep manunggaling kawula gusti sekaligus syatahat nampak dalam beberapa puisi, misalnya: "Akuarium", "Muara", "Dalam Diriku" dan puisi "Sonet: x". Sebagai contoh di tampilkan puisi "Sonet: X" berikut ini:

Sonet: X

siapa menggores di langit biru siapa meretas di awan lalu siapa mengkiristal di kabut itu

siapa mengertap di bunga layu

siapa cerna di warna ungu siapa bernafas di detak waktu siapa berkelebat setiap kubuka pintu siapa mencair di bawah pandangku

siapa terucap di celah-celah kataku

siapa mengaduh di baying-bayang sepiku siapa tiba menjemputku berburu siapa tiba-tiba menyibak cadarku siapa meledak dalam diriku : siapa Aku

Dalam sajak di atas kata "siapa" direpetisikan dalam setiap baris, hal ini menunjukkan bagaiamana pertanyaan tentang awal mula yang menjadi permulaan menuju tangga proses manunggaling kawula gusti. Rangkaian pertanyaan tentang "siapa-ku" terjawab dengan nada retoris di akhir sajak, yakni Aku dengan huruf A besar. Ini menunjukkan sampainya kesadaran dari pertanyaan tentang "ku" dengan huruf "k" kecil akhirnya bermuara pada "Aku" dalam huruf A besar. Pertanyaan "siapa" terkait "ku" huruf kecil Tuhan kecuali Tuhan". 
terjawab dengan "Aku” huruf besar. Terjadi kesejajaran antara "ku" huruf kecil dengan "Aku" huruf besar. Seorang hamba (kawula) telah bersatu dengan Tuhannya (Gustinya). Tidak ada lagi atau tidak disadari lagi wujud "ku” karena "ku” sama dengan "Aku”; "siapa meledak dalam diriku/ : siapa Aku”.

\section{Simpulan}

Dari uraian di atas nampak sajak-sajak SDD dibangun dari kata atau bahasa yang mempesona dengan bertumpu pada ragam bunyi(terutama cacaphony), pemilihan diksi , citraan dan imaji yang kuat dan efektif sekaligus penggalian simbol yang kuat terutama natural symbol dan privat symbol. sehingga mampu membangun suasana tertentu.

Puisi-puisi SDD banyak terinspirasi dari konsep-konsep mistisme dalam kosmologi Jawa, sajak-sajak SDD dalam kumpulan puisi Hujan Bulan Juni ini dapat hadir sebagai kisah sekaligus berita pemikiran. Sebagai kisah sekaligus berita pikiran, puisi-puisi SDD sebenarnya hadir sebagai sistem lambang budaya yang merupakan hasil kegiatan intelektual penyairnya yang berada di lingkungan masyarakat budaya yang majemuk. Puisi-puisi tersebut muncul dengan sekaligus menampilkan fakta kemanusiaan, fakta kejiwaan dan fakta kesadaran kolektif sosio kultural di mana ia diciptakan.

Secara implisit sajak-sajak SDD dalam Hujan Bulan Juni berusaha melakukan upaya penyosokan atau pencitraan tentang eksistensi manusia beserta beragam persoalan kema- nusiaan. Sosok dan citra tentang manusia itu muncul secara tersirat dan mempribadi sesuai dengan kodrat puisi yang minim unsur naratifnya. Hal ini terjadi karena naluri SDD sebagai penyair cenderung meletakkan dirinya sendiri dan memandang dirinya sebagai sosok orientasi dari pergumulan dan ketegangan antara dirinya dengan realitas sosial budaya yang melingkupinya.

Sajak-sajak SDD dalam kumpulan $H u$ jan Bulan Juni ini juga menunjukkan konsep dan pandangan SDD bahwa puisi tidak sekedar menjadi reproduksi dari realita, melainkan sesuatu yang mempertajam, membuat penghayatan manusia terhadap realitas menjadi lebih intens. Teks puisi SDD merupakan contoh betapa sebuah karya sastra dapat secara jujur menghadirkan kegelisahan manusia dan mampu membuka dialog dengan pembacanya dengan membutuhkan kemampuan berkognifikasi, pelibatan unsur emotif dan perefleksian diri. Melalui sajak-sajaknya itu pembaca dipaksa untuk bergumul dengan dirinya sendiri dengan membandingkan, meresapi, dan merefleksi bahkan mengidentifikasi diri. 


\section{Daftar Pustaka}

Adisaswmita, K, Sumidi. 1977. Santapan Rohani Bagi Para Mangudi Karahayon. Yogyakarta: Yayasa Sosrokartono.

Al-Ma'ruf, Ali Imron. 2012. Stilistika Teori Metode, dan Aplikasi Pengkajian Estetika Bahasa. Surakarta: Cakrabooks.

Amir, Hazim. 1991. Nilai-nilai Etis dalam Wayang._Jakarta: Sinar Harapan.

Atmoswito, Subiyantoro. 1989. Perihal Sastra dan religiusitas dalam Sastra. Bandung: Sinar Baru.

Adimasana, Jb. 1986. Ki Ageng Suryamentaraman: Tentang Citra Manusia. Yogyakarta: Kanisius.

Burckhard, Titus. 1984. Mengenal Ajaran Kaum Sufi. Jakrta: Pustaka Jaya.

Ciptoprawira, Abdullah. Tanpa tahun. Filsafat Jawa: Manusia dalam Tiga Dimensi

Kehidupan. Yogyakarta: Proyek Javanologi.

Damono, Sapardi Djoko. 2013. Hujan Bulan Juni. Jakarta:Gramedia Pustaka

Damono, Sapardi Djoko. 2010. Simbolisme dan Imajisme dalam Sastra Indonesia. Jakarta: Pusat Bahasa.

Hadiwiyono, Harun. 1982. Konsepsi Tentang manusia dalam Konsepsi kebatinan Jawa. Jakarta: Sinar Harapan.

Kayam, Umar. 1989. Transformasi Budaya Kita. Horison, XXIV (08, 09, 10): 256 - 269;292 $-298 ; 328-335$.

Kleden, Ignas. 1987. Sikap Ilmiah dan Kritik Kebudayaan. Jakarta: LP3ES.

Leeech, Goofrey and Mick Short. 2007. Stille and Fiction, a Linguistic Introduction to English Fictional Prose. London: Longman.

Mahayana, Maman S. 2001. Akar Melayu. Magelang: Indonesia Tera.

Mahayana, Maman. S. 2005. 9 Jawaban Sastra Indonesia. Jakarta: Bening Publishing.

Naim, Mochtar. 1999. Demokrasi dalam Dialektika Kebudayaan Nusantara, dalam Pembebasan Budaya-budaya Kita. Jakarta: Gramedia

Newton, K.M. (Terjemahan Dr. Soelistia, ML.). 1994. Menafsirkan Teks: Pengantar Kritis kepada Teori dan Praktek Penafsiran Sastra. Semarang: IKIP Semarang Press.

Nurgiyantoro, Burhan.. 2014. Stilistika. Yogyakarta: Gajah Mada University Press.

Ricour, Paul (Penyunting Mario J. Valdes). 1991. Reflection and Imagination: A Ricour Reader. 
New York: Harvester Wheatsheaf.

Rosidi, Ajip. 1995. Sastra dan Budaya Kedaerahan dalam KeIndonesiaan. Jakarta: Pustaka Jaya.

Naim, Mochtar. 1999. Demokrasi dalam Dialektika Kebudayaan Nusantara, dalam Pembebasan Budaya-budaya Kita. Jakarta: Gramedia

Simpson, Paul. 2004. Stylistic a Resource Book for Children. London \& New York: Routledge.

Sunardi, ST. 2003. Opera Tanpa Kata. Yogyakarta: Buku baik.

Sugiharto, Bambang. 2003. Kebudayaan, Filsafat dan Seni. Bentara, Kompas, Rabu 3 Desember.

Subagya, Rahmat. 1976. Kepercayaan, Kebatinan, Kerohanian dan Agama. Yogyakarta: Kanisius.

Tanpoaran. Tanpa tahun. Sangkan Paraning Dumadi. Surabaya: Yayasan Joyoboyo

Weelek, Renne dan Austin Wareen. Terrj Melani Budianto, 1989. Teori Kesusastraan. Jakarta: Gramedia.

Widijanto, Tjahjono. 2011. Sastra Kapujanggan Hingga Kapitalisme: Segugusan Esai Sastra. Surabaya: Buku Kita. 